\title{
Sustainability risks $\&$ opportunities in the insurance industry
}

\author{
Nadine Gatzert · Philipp Reichel (D) A Armin Zitzmann
}

\begin{abstract}
The aim of this paper is to provide an overview of relevant sustainability risks and opportunities in the insurance industry, where we address the asset side, the liability side, and a broader corporate perspective. Furthermore, we discuss approaches on how insurers can deal with these sustainability risks and opportunities, and provide selected empirical insight from the literature and (industry) surveys on current practices mostly for the European market. Our study emphasizes that while climate change represents an important factor in this context, it is by far not the only one. Insurers should thus take a broader approach on managing sustainability risks and opportunities. Furthermore, key barriers include a lack of data and knowledge, which impede transparency between firms with respect to their sustainable management approach.
\end{abstract}

Keywords Sustainability · Environmental social and governance (ESG) · Corporate social responsibility (CSR)

JEL Classification $\mathrm{G} 20 \cdot \mathrm{G} 22 \cdot \mathrm{G} 23$

N. Gatzert · P. Reichel $(\bowtie)$

School of Business, Economics and Society, Chair of Insurance Economics and Risk Management, Friedrich-Alexander University Erlangen-Nürnberg (FAU), Lange Gasse 20, 90403 Nuremberg, Germany

E-Mail: philipp.reichel@fau.de

N. Gatzert

E-Mail: nadine.gatzert@fau.de

A. Zitzmann

CEO, NÜRNBERGER Versicherung, Nuremberg, Germany

E-Mail: armin.zitzmann@ nuernberger.de 
Zusammenfassung Das Ziel dieser Forschungsarbeit ist es, einen detaillierten Überblick über relevante Nachhaltigkeitsrisiken und -chancen innerhalb der Versicherungsbranche zu geben, unterteilt nach Kapitalanlage- und Versicherungsgeschäft sowie aus einer gesamtheitlichen unternehmerischen Sicht. Darüber hinaus diskutieren wir Ansätze, wie Versicherer mit diesen Nachhaltigkeitsrisiken und -chancen umgehen können und präsentieren ausgewählte Erkenntnisse aus der empirischen Literatur sowie aus (industriebezogenen) Studien zu aktuellen Vorgehensweisen in der Praxis mit Fokus auf den europäischen Markt. Obwohl der Klimawandel hierbei sehr relevant ist, stellt er bei weitem nicht den einzigen Faktor dar. Versicherungsunternehmen sollten deshalb für den Umgang mit Nachhaltigkeitsrisiken und -chancen einen umfassenderen Ansatz wählen. Zentrale Hindernisse, die die Transparenz hinsichtlich nachhaltiger Managementansätze in Unternehmen derzeit noch beeinträchtigen, sind insbesondere ein Mangel an Daten und Wissen.

\section{Introduction}

Sustainability risks and opportunities are of increasing relevance for insurance companies with a strong potential to affect all business units and risk types. They typically cannot be easily assessed due to the high uncertainty in regard to the future extent and time horizon of sustainability risks, also given the interaction effects between physical consequences and transition risks (BaFin 2020, p. 18). In this paper, we emphasize that sustainability risks and opportunities go considerably beyond climate change, even though this is one major issue in this context, and that there are various barriers that hinder transparency.

In the literature, numerous aspects have been addressed. For instance, Scholtens (2011) focuses on insurers' corporate social responsibility (CSR), while Scordis et al. (2014) describe the risk management and value resulting from applying the Principles for Sustainable Insurance (PSI), which are discussed in more detail later. Furthermore, specific regions (for the Brazilian case, see, e.g., Nogueira et al. 2018), specific issues (for the climate change case, see, e.g., Mills 2009) and certain activities (for sustainable investing by Swiss banks and insurers, see, e.g., Risi 2020) in the sustainability context are considered as well. However, to the best of our knowledge, a general overview on sustainability risks and opportunities emerging from the corporate perspective with a structured presentation of both sides of an insurer's balance sheet has not been done so far. We contribute to previous work by discussing main sustainability risks and opportunities on the asset side, the liability side, and from a broader corporate perspective. For each category, we additionally present selected approaches how insurers can deal with these risks and opportunities, and further provide empirical insight.

The paper is structured as follows. Sect. 2 addresses the terminology and regulatory initiatives of relevance for insurers. Sect. 3 focuses on sustainability risks and opportunities in the insurance industry, and Sect. 4 summarizes the paper. 


\section{Terminology and (regulatory) initiatives with relevance for insurers}

In 2015, the 17 Sustainable Development ${ }^{1}$ Goals (SDGs) were developed and adopted by all UN member states, to be achieved until $2030,{ }^{2}$ as "the blueprint to achieve a better and more sustainable future for all. They address the global challenges we face, including poverty, inequality, climate change, environmental degradation, peace and justice"'s.

The German National CSR Forum also emphasizes that corporate social responsibility is a narrower concept than sustainability, as it means the company's specific contribution to sustainability/sustainable economic activity. ${ }^{4}$ The Forum also refers to a number of well-known guidelines and principles in this context, published by, e.g., the International Labour Organization or the United Nations, saying that "CSR refers to a company's responsibility for its impact on society. This includes social, environmental and economic aspects, [...]. More specifically, CSR for example involves fair business practices, staff-oriented human resource management, economical use of natural resources, protection of the climate and environment, sincere commitment to the local community and also responsibility along the global supply chain"5. With reference to previous work, Scholtens (2011, p. 144) also states that CSR "relate[s] a firm's operations to the various dimensions of sustainable development", where "firms attempt to take account of their employees, customers and other stakeholders (people), natural environment (planet), and future prospects of the firm (profit)". CSR is thus a multidimensional concept, which makes measurement generally complex and not easily standardized, which is also one reason why the literature observes a missing consensus concerning the meaning of sustainability and CSR (for a discussion and summary of these issues, see, e.g., Scordis et al. 2014; Nogueira et al. 2018).

To assess the CSR of insurance companies with its various dimensions, Scholtens (2011, p. 145), for instance, uses 23 indicators within four categories: 1) CSR reporting, behavioral codes, and environmental care systems, 2) environmental responsibility in practice, 3) social-economical activities, and 4) governance codes. ${ }^{6}$ Dimensions and criteria can also be implied from ratings and sustainability indices, whereby transparency about criteria and weights might be somewhat limited. This is also indicated by empirical observations regarding a lack of convergence (level,

\footnotetext{
1 The well-known Our Common Future (or Brundtland) report contains a fundamental and often referred to definition of sustainable development: "Humanity has the ability to make development sustainable- to ensure that it meets the needs of the present without compromising the ability of future generations to meet their own needs" (World Commission on Environment and Development 1987, p. 24).

2 https://www.un.org/sustainabledevelopment/development-agenda/, access 05/14/2020.

3 https://www.un.org/sustainabledevelopment/sustainable-development-goals/, access 05/14/2020.

4 https://www.csr-in-deutschland.de/DE/Was-ist-CSR/Grundlagen/Nachhaltigkeit-und-CSR/nachhaltig keit-und-csr.html, access 05/14/2020.

5 https://www.csr-in-deutschland.de/EN/What-is-CSR/Background/Sustainability-and-CSR/ sustainability-and-csr-article.html, access 05/15/2020.

6 The framework is based on Scholtens (2009, p. 162), which was developed for assessing the CSR of international banks and did not include governance and compliance criteria due to comprehensive regulatory requirements.
} 
distribution and risk) in measuring environmental, social and governance (ESG) performance by different rating providers (e.g. Dorfleitner et al. 2015, p. 465), which is a key problem in practice. ${ }^{7}$

In addition to the selected approaches to assess the CSR presented above, insurers might be signatories of initiatives, which also require the compliance with certain principles. Specifically developed for the insurance industry are the Principles for Sustainable Insurance (PSI), for instance. The principles' underlying concept of sustainable insurance has the objectives to "reduce risk, develop innovative solutions, improve business performance, and contribute to environmental, social and economic sustainability" to extending corporate risk management. ${ }^{9}$

Of high relevance in the investment context and also referenced by the PSI are the six UN-backed Principles for Responsible Investment (UN-PRI) ${ }^{10}$ with its about 2500 signatories managing close to 90 trillion USD in assets, which define the term responsible investment as "a strategy and practice to incorporate [...] [ESG] factors in investment decisions and active ownership" ". According to empirical findings in Gatzert and Reichel (2020b), ESG criteria, responsible investment as a term as well as the UN-PRI are among the most often cited concepts in European and US insurers' annual reports and sustainability documents. A list of selected ESG factors according to the UN-PRI is provided in Table 1. We finally note that one main focus in the CSR discussion is climate change, given its special relevance for insurers (e.g. Stechemesser et al. 2015; Golnaraghi 2018; Gatzert and Reichel 2020a).

Regulatory and market-led initiatives represent another driving force concerning sustainability-related measures and changes in the business model of insurers. The UN-PRI global sustainable finance policy database on policy tools and market-led

\footnotetext{
7 For instance, MSCI offers a rating scale similar to credit ratings (AAA to CCC for leaders to laggards) and assesses a firm's industry-adjusted ESG risk exposure and its ESG risk management capacities in relation to its peer group. As of June 2020, MSCI lists 37 ESG Key Issues in the measurement context (https://www.msci.com/esg-ratings, access 07/19/2020).

8 See UNEP FI (2012, p. 3). They further state that "[s]ustainable insurance is a strategic approach where all activities in the insurance value chain, including interactions with stakeholders, are done in a responsible and forward-looking way by identifying, assessing, managing and monitoring risks and opportunities associated with environmental, social and governance issues" (UNEP FI 2012, p. 3).

9 "The PSI promote strategic management of risk. They encourage insurers to identify future risks from environmental, social, and governance sources and then use these new data to inform their processes. They also encourage the development of products that can be used to manage uncertainty and finance macroeconomic risk. Thus, the PSI expand the practice of risk management as they encourage thinking in terms of uncertainty and the long term, rather than in terms of risk and the short term" (Scordis et al. 2014, p. 270).

10 Principles 1-6 include the commitment that "[w]e will incorporate ESG issues into investment analysis and decision-making processes[,] [...] be active owners and incorporate ESG issues into our ownership policies and practices[,] [...] seek appropriate disclosure on ESG issues by the entities in which we invest[,] [...] promote acceptance and implementation of the Principles within the investment industry[,] [...] work together to enhance our effectiveness in implementing the Principles[,] [...] report on our activities and progress towards implementing the Principles" (https://www.unpri.org/pri/what-are-the-principlesfor-responsible-investment, access 08/20/2020).

11 https://www.unpri.org/download?ac=10223, access 06/04/2020. See Sect. 3.1 for further investmentrelated initiatives, terminologies and strategies.
} 
Table 1 Examples of ESG factors according to the PRI Association (2018b, p. 3) ${ }^{\mathrm{a}}$

\begin{tabular}{lll}
\hline Environmental issues & Social issues & Governance issues \\
\hline Climate change & Human rights & Board structure, size, diversity, \\
Renewable energy & Workplace health and safety & skills and independence \\
Air, water or resource & Human capital management and & Executive pay \\
depletion or pollution & employee relations & Bribery and corruption \\
Changes in land use & Diversity & Internal controls and risk \\
& Controversial weapons & management \\
\hline
\end{tabular}

aSee also the UN-PRI website on ESG issues offering insights on current crucial issues such as fracking, conflict zones and cyber security (https://www.unpri.org/esg-issues, access 05/15/2020)

initiatives with a special investment focus shows a strong increase in regulations and policy interventions over time, to more than 500 in 2019 with more than 80 new or revised policy instruments in 2019 alone. The UN-PRI database can be of interest for stakeholders including investors, insurers, researchers and regulators to gain insights into issues like responsible authorities and voluntary or mandatory interventions related to (specific) ESG factors in specific regions and sectors, among others. ${ }^{12}$

With respect to recent developments in insurance regulation concerning the consideration of sustainability risks and opportunities, the review of Solvency II as well as the "Regulation (EU) 2019/2088" on sustainability-related disclosure requirements in the financial services sector (SFDR) are of major relevance, taking into account the European Green Deal and contributing to the three targets of the EU Commission's Action Plan on sustainable finance. The SFDR requires, for instance, financial market participants and financial advisers ${ }^{13}$ from March 2021 on to disclose information concerning the consideration of sustainability risks in the investment (decision) or insurance advice process and at the product level. ${ }^{14}$

\section{Sustainability risks \& opportunities in the insurance industry}

\subsection{Sustainability risks and opportunities on the insurer's asset side}

\subsubsection{Sustainability risks and opportunities on the asset side: overview}

Against the background of insurers' significant investment volumes, sustainability risks and opportunities on the asset side are of high relevance.

\footnotetext{
12 https://www.unpri.org/sustainable-markets/regulation-map, access 05/15/2020.

13 This includes asset managers, institutions for occupational retirement provision as well as insurers and intermediaries offering (advice on) so-called insurance-based investment products (https://eurlex.europa.eu/legal-content/EN/TXT/PDF/?uri=CELEX:32019R2088\&qid=1583337894850\&from=EN, access 06/17/2020).

14 https://eur-lex.europa.eu/legal-content/EN/TXT/PDF/?uri=CELEX:52018DC0097\&from=EN, access 06/17/2020; https://ec.europa.eu/info/sites/info/files/business_economy_euro/banking_and_finance/ documents/2020-solvency-2-review-consultation-document_en.pdf, access 07/21/2020; https://eur-lex. europa.eu/legal-content/EN/TXT/PDF/?uri=CELEX:32019R2088\&qid=1583337894850\&from=EN, access $06 / 17 / 2020$.
} 
Major issues that can potentially arise from sustainability risks on the asset side include credit risk, market (price) risk, and liquidity risk, ${ }^{15}$ as described by, e.g., the German supervisory authority BaFin (2020, p. 18) with the following examples: Credit or counterparty risk can materialize if a company (partially) defaults due to political decisions with respect to ESG aspects that negatively impact the company's business model such as a carbon dioxide (CO2) tax. ${ }^{16}$ Market expectations regarding such political or regulatory ESG measures can also imply market (price) risk of nonsustainable investments by way of depreciation. Finally, liquidity risk may arise in case of a natural catastrophe where a significant number of customers withdraws funds from their accounts to finance losses. Besides climate risks being the dominant issue, further ESG risks, including water scarcity and their impact on assets, are increasingly assessed by financial firms as well (UNEP 2017, p. 41). Other relevant issues or themes are further presented in the Impact Investing Market Map, including renewable energy, education or health (PRI Association 2018a).

While risks can arise from investing in firms that are vulnerable to the consequences of future climate change, for instance, opportunities arise as well when focusing on companies that are particularly resilient to such a development as already emphasized by Herweijer et al. (2009, p. 365). They point out that such an analysis is of high relevance for climate-sensitive sectors, including real estate, municipal bonds and infrastructure funds. An identification of investment opportunities in terms of sustainable firms and projects should also take into account the investment time horizon with a forward-looking approach (Herweijer et al. 2009, p. 365), which is still a valid recommendation today.

Insurance companies might also seize sustainability opportunities by investing in infrastructure projects and by forming public-private partnerships. Swiss $\operatorname{Re}(2020$, p. 23) for instance, estimates "an annual USD 920 billion opportunity for longterm investors over the next 20 years" in emerging markets and expects that "[infrastructure] projects can deliver attractive yields to help insurers match their long-term liabilities, while also offering region and asset class diversification, and opportunity for environmentally and socially responsible investing". ${ }^{17}$ A large amount of financial resources is also needed for the transition towards a decarbonized and climateresilient infrastructure. Insurance companies are seen as a possible key investor in this context (Golnaraghi 2018).

\footnotetext{
${ }^{15}$ We further discuss strategic and reputational risks from the overall corporate perspective in Sect. 3.3, which (indirectly) also relate to the asset side.

16 With respect to credit risk, the UN-PRI-related Statement on ESG in credit risk and ratings offers an overview on ESG issues and risks on the corporate and sovereign level as well as how rating agencies and investors can act in this context (https://www.unpri.org/credit-ratings/statement-on-esg-in-creditrisk-and-ratings-available-in-different-languages/77.article, access 06/08/2020). Simulations performed by Standard \& Poor's Ratings Services (2015), for instance, show a possible negative impact of natural catastrophes (250-year event) on sovereign credit ratings up to two notches. Catastrophe insurance coverage represents a mitigating factor in this context.

${ }^{17}$ Investments in this asset class would allow them to contribute, for instance, to SDG 9 (industry, innovation and infrastructure) (https://www.un.org/sustainabledevelopment/infrastructure-industrialization/, access 06/17/2020).
} 
However, there also exists a number of obstacles which need to be removed first so that insurers can unfold the full potential of their financial capacity, such as complex regulatory restrictions and capital requirements (Golnaraghi 2018), a lack of transparency with respect to data or an insufficient availability of infrastructure investment opportunities in the market (Gatzert and Kosub 2017).

\subsubsection{How to deal with sustainability risks and opportunities on the asset side}

Given that there is a multitude of definitions and concepts, we follow the GSIA (2019, p. 3) as a global sustainable investment organizations' network by applying the "inclusive definition of sustainable investing, without drawing distinctions between this and related terms such as responsible investing and socially responsible investing" (see also Gatzert and Reichel 2020b). Insurance companies might follow the UN-PRI (or in a broader sense the PSI) in order to apply a sustainable investment approach. In this context, sustainable investment strategies most often include ESG incorporation as an approach, where "asset managers complement traditional, quantitative techniques of analyzing financial risk and return with qualitative and quantitative analyses of ESG policies, performance, practices and impacts" (USSIF 2018, p. 13). ${ }^{18}$ ESG incorporation is typically considered to comprise strategies such as ESG integration, negative screening, positive/best-in-class screening and sustainability themed investing. Next to ESG incorporation, engagement (active ownership) represents an additional strategy (PRI Association 2018b; USSIF 2018). ${ }^{19}$ Besides implementing (selected) strategies through their own asset manager, insurers might alternatively use external providers including asset management firms or rating agencies (services).

Apart from sustainable investment strategies and asset classes, asset risks can also be assessed by conducting scenario analyses, thereby taking into account, e.g., the recommendations of the Financial Stability Board's Task Force on Climaterelated Financial Disclosures (TCFD 2017b) with respect to transition scenarios and broader physical scenarios of climate change with relevance for both assets and liabilities. Transition scenarios provide "plausible pathways to particular target outcomes" (TCFD 2017b, p. 15) (without statistical likelihoods), e.g. a transition towards a low-carbon economy, a $2{ }^{\circ} \mathrm{C}$ scenario, certain $\mathrm{CO} 2$ concentration levels,

\footnotetext{
18 The PRI Association (2018b, p. 5) defines ESG incorporation as "the review and use of ESG information in the investment decision-making process". See Gatzert and Reichel (2020b) for a more detailed presentation.

19 As already mentioned by Gatzert and Reichel (2020b), USSIF (2018) includes impact investing as independent strategy, while the PRI Association (2018a, 2018b) does not directly consider it in its definitional framework, but follows up on this strategy, e.g. with its Impact Investing Market Map or by considering it as part of a thematic approach (https://www.unpri.org/download?ac=10223, access 06/04/2020). By contrast, the PRI Association (2018b) takes into account norms-based screening as well as a combination of these strategies.
} 
or a net-zero greenhouse gas (GHG) emissions scenario by $2050 .{ }^{20}$ The process can thus be helpful for firms to understand the time horizon and the potential negative or positive (financial) impact of such a transition towards a low-carbon economy on various industry sectors depending on, e.g., their energy demand and energy prices (BaFin 2020, p. 35). Physical scenarios use outputs of global climate models to focus on the (financial) impact of physical risks from climate change such as from drought or flooding. However, the downscaling of these scenarios to the impact on a regional or local level seems to need further work (TCFD 2017b, p. 24), which also represents a barrier for a broad practical application in insurance companies, as (regional) flood or heavy rain are difficult (if at all) to predict, with resulting uncertainty regarding their impact on firms and thus asset values. Furthermore, the BaFin (2020, p. 35) also cautions that some of the scenarios in transition risk assessment based on IAM were deemed inappropriate. ${ }^{21}$

With respect to climate scenario analyses of the investment portfolio, the UNPRI supported $2^{\circ}$ Investing Initiative offers an open-source and free of charge tool in this context, also known as the Paris Agreement Capital Transition Assessment or PACTA tool. Until June 2020, around 1000 financial firms have already used the online tool in order to assess the impact of a $2{ }^{\circ} \mathrm{C}$ scenario transition on their listed equity and corporate bonds investment portfolios, which also allows to align with the TCFD (2017a) recommendations. The initiative also collaborates with several supervisory authorities such as the European Insurance and Occupational Pensions Authority (EIOPA). ${ }^{22}$

An application of the TCFD (2017b) recommendations is also conducted by a Working Group coordinated by the Finance Initiative of UN Environment with focus on the banking industry, which resulted in two publications. While the UNEP (2018) report as first part focuses on the assessment of the potential impact of a lowcarbon policy and technological transition to mitigate climate change on the credit risk of corporate loan portfolios, i.e. transition risks and opportunities, the second report by UN Environment (2018) also concentrates on risks and opportunities emerging from corporate loan portfolios, but related to physical impacts.

In UNEP (2018), three scenarios with a $1.5^{\circ} \mathrm{C}, 2{ }^{\circ} \mathrm{C}$, and $4{ }^{\circ} \mathrm{C}$ global average temperature increase until the year 2100 are tested in the sense of a sensitivity analysis. To assess transition risks for a firm from the energy sector, for instance, scenarios model its future energy mix along with other variables such as electricity prices, and then the resulting revenues and (emissions) costs among other financial

\footnotetext{
20 See TCFD (2017b, p. 21) for an overview of various transition scenarios with the respective underlying assumptions. The UNEP (2018, p. 17) states that "[t]ransition scenarios describe an evolving economic environment in a consistent manner across time, sectors, and geographies. Each transition scenario provides detailed outputs which help assess the economic impact on sectors", including the respective sector's sensitivity towards risk factor pathways. One type of scenario pathways is derived based on Integrated Assessment Models (IAM), which are also used for physical risk assessment and point out different ways concerning the limitation of global warming towards a $2^{\circ} \mathrm{C}$ scenario (TCFD 2017b, p. 18). IAM "model interactions between anthropogenic greenhouse gas emissions in climate systems and climate change impacts on social-economic systems" (TCFD 2017b, p. 24).

21 See Krogstrup and Oman (2019, pp. 41-42) for the referenced discussion.

22 https://www.transitionmonitor.com/, access 06/03/2020.
} 
variables. They also compare high vs. low carbon intensity/regulated and unregulated segments. The presented case studies further focus on oil and gas as well as the metal and mining sectors. In addition, a market opportunities assessment is done to identify attractive segments, which is then contrasted with the bank's capabilities (competitive market, risk appetite, operational capacity) (UNEP 2018, pp. 60-61).

UN Environment (2018, p. 9) continues this work by focusing on physical risks of climate change, taking into account both incremental climate shifts as well as changes in extreme climate events. The impact on the credit risk of agriculture and energy sector portfolios is assessed by looking at sector productivity, revenue and cost of goods sold, and the probability of default, as well as the effect on real estate portfolios (property values, loan-to-value ratios).

In addition or instead of long-term temperature-based scenarios, stress tests can be conducted to assess the effect of sudden changes in policies and technologies on credit and market risks, for instance (UNEP 2018, p. 10). However, as laid out above, the transfer and applicability of scenarios to (e.g. regional) settings and the assessment of the impact is likely highly difficult in practice for many insurers.

\subsubsection{Empirical insight from the literature and (industry) surveys on current practices}

In their text mining analysis of annual, sustainability- and investment-related reports and documents of listed European and US insurance companies, Gatzert and Reichel (2020b) observe a strong increase in the number of insurers with a sustainable investment approach over time, especially in the European insurance market. Most important are the application of impact investing and ESG integration in reports and documents, which is also supported by the Geneva Association survey in Golnaraghi (2018) based on interviews with 62 C-level executives from 21 international (re-) insurance companies. Gatzert and Reichel (2020b) find that this ranking has been rather stable over time and does not substantially differ for the considered European and US insurance companies.

However, despite the increasing consideration of ESG issues by insurers, Golnaraghi (2018) concludes that insurance companies are still confronted with numerous challenges on the asset side. The challenges for insurers aiming to support a transition towards a low-carbon economy, and also of relevance for ESG issues, are broken down into five areas (major issues in brackets): financing and marketrelated factors (lack of general standards and definitions), financial and insurance regulations (regulatory capital requirements), climate change-related policies and regulatory frameworks (uncertainties), technology (risk-return issues in the markets for green technologies) and data and transparency for informed investing (standardization in reporting and stress testing) (Golnaraghi 2018, pp. 21-22).

One key barrier in the investment context thereby represents the first and last area, i.e. the lack of knowledge and data, as ESG data is typically only available for listed (and large-cap) firms and generally not for corporate bonds of small and mediumsized enterprises, which however are relevant for insurers' asset portfolios. To add to the complexity, whether a business model is "sustainable" or not may also depend on the region (e.g. sufficient water sources etc.). With respect to thermal coal mining or 
coal power generation, different di- or investment approaches exist in the insurers' asset management as well. ${ }^{23}$ Further problems arise from the question of (out- $/$ under-)performance of these investments, which is strongly mixed (see discussion in Sect. 3.4). Moreover, high costs can arise from ESG integration and other techniques (Golnaraghi 2018), and institutional investors also mention valuation and modeling limitations in the context of ESG integration (OECD 2017, p. 37). Against this background, most insurers use ESG ratings of firms by MSCI (Golnaraghi 2018).

Overall, these challenges might represent a possible explanation that $41 \%$ of the 80 largest insurers worldwide still lack a climate-aligned investment approach as highlighted by the AODP\&SA (2018) survey. Climate scenario and portfolio emissions analyses continue to be rather in their early stages as well and around $1 \%$ of the assets under management are estimated as low-carbon investment.

Besides the UN-PRI initiative, other current initiatives that might intensify the application of sustainable investment strategies on the asset side of insurers and thus increase the future transparency of climate risk exposures, include the $U N$ convened Net-Zero Asset Owner Alliance, which was initiated in 2019. By aligning investments with the Paris Agreement, i.e. a $1.5^{\circ} \mathrm{C}$ scenario, the aim of net-zero GHG emissions within institutional investors' portfolios shall be accomplished in 2050 at the latest. ${ }^{24}$ Furthermore, signatories of the Montréal Carbon Pledge, another UN-PRI supported initiative, make a commitment to annually capture, publish and lower their investments' carbon footprint. ${ }^{25}$ Also, since 2000, the stakeholder-driven Carbon Disclosure Project supports firms and public bodies (e.g. cities or states) to identify, manage and disclose risks and opportunities resulting from environmental issues with a special focus on climate change. ${ }^{26}$

\subsection{Sustainability risks and opportunities on the insurer's liability side}

\subsubsection{Sustainability risks and opportunities on the liability side: overview}

On the liability side, climate change plays a particularly important role. For instance, Munich Re estimates 150 billion USD economic losses for 2019 due to natural disasters, of which about one third were insured. ${ }^{27}$

\footnotetext{
23 Documented di- or investment approaches are, e.g., based on the share of coal-related business (e.g. $30 \%$ of revenues), remain invested as fossil fuel intensive energy corporations drive long-term green and clean technologies investments or exclude sector investments and underwriting services at the same time (Golnaraghi 2018). A survey published by Asset Owners Disclosure Project \& ShareAction (AODP\&SA 2018) captures a missing application on passive mandates as well as of the Urgewald's Global Coal criteria as one of the most extensive guidelines. A call for an industry-wide taxonomy standard, including defined exclusion approaches, is added in this context.

24 https://www.unepfi.org/net-zero-alliance/, access 05/16/2020.

25 https://montrealpledge.org/, access 07/20/2020. The internet presence also includes the five steps for implementation.

26 https://www.cdp.net/en/info/about-us/what-we-do, access 07/20/2020. According to the referenced Carbon Disclosure Project website, requests for support of the Carbon Disclosure Project come from over 500 investors with over 100 trillion USD in assets.

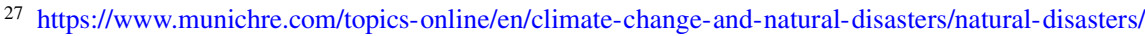
natural-disasters-of-2019-in-figures-tropical-cyclones-cause-highest-losses.html, access 05/16/2020.
} 
In regard to such sustainability risks on the liability side, the German supervisory authority BaFin (2020, p. 18) points out potentially adverse changes in underwriting risks with increasing losses in property insurance (e.g., from an increasing number and severity of storms, flooding or hail) as well as business interruption insurance. They emphasize that this should be adequately taken into account in technical reserves, and that these risks cannot only hit the liability side, but also the asset side of the balance sheet. Also, Golnaraghi (2018, p. 7) refers to Carney (2015, p. 6), who lists liability risks in addition to physical risks and transition risks, which may arise from compensation claims made by parties incurring climate change-related damage or loss.

With focus on climate change and weather risks, Herweijer et al. (2009, pp. 362-364) further differentiate between short-term and long-term effects on underwriting practices, as a forward-looking risk perspective with risk-based pricing is already needed in the short-term to account for the fact that historical data is not sufficient for calibrating risk models, which is still relevant today. In the long run, there might even be limits of insurability in regard to affordability and availability of coverage due to correlated risks. Examples named are coastal and inland flooding due to sea level rise along with "super catastrophes" that might increase correlations across regions, business lines and coverages. This is also in line with a UNEP (2017) report, which states that besides natural disasters and climate change, access to and affordability of insurance protection are among the three major sustainability challenges for the insurance sector. ${ }^{28}$

Opportunities can arise from a potentially increasing insurance demand (depending on the market and type of risk ${ }^{29}$ as well as (green) product innovation and microinsurance, that also encourage risk-reducing behavior, and service innovation by way of climate change risk management services, for instance (Maynard 2008; Herweijer et al. 2009; Mills 2009; Stechemesser et al. 2015). ${ }^{30}$

Besides the product- and service-level, insurance companies can also adapt and benefit through incentivizing low-carbon-related purchases/assets by offering insurance premium differentiation or being transparent on risk and claims performance

\footnotetext{
28 Both combined are pivotal for financial inclusion, particularly in emerging and developing countries, and influence economic and investment activities, among others (UNEP 2017). See also Stechemesser et al. (2015, pp. 562-563) for a summary of possible climate change impacts on insurers' key underwriting figures derived from the literature, also taking into account insurability.

29 For instance, Swiss Re (2020, pp. 28-29) expects that a surge in infrastructure projects in the seven largest emerging markets leads to a 50 billion USD insurance premium opportunity with 9.7 billion USD related to insuring renewable energy projects until 2030. At the same time, however, the demand for natural hazard insurance such as floods remains low in Germany, for instance, even in highly exposed regions (Surminski et al. 2020, p. 28). Reasons for the low demand include difficulties in obtaining coverage in high/extreme risk zones (which has been extended; now limitations only concern $0.6 \%$ of current building stock) or a lower awareness in less exposed areas, along with the possible expectation that the state covers losses as was done in the past; also, the introduction of a compulsory flood insurance scheme failed twice in 2004 and 2015 (Surminski et al. 2020).

30 See also the following industry example from September 2020 by Munich Re, who now offers a modular software solution that "allows companies to analyse the risks of climate change for their assets or liabilities on a location-specific basis" (https://www.munichre.com/en/company/media-relations/ media-information-and-corporate-news/corporate-news/2020/2020-09-01-standard-chartered.html, access 09/17/2020).
} 
when underwriting low-carbon assets such as green buildings (UNEP 2017, p. 40). The UNEP (2017, p. 40) report also propagates "to tag claims linked to the asset's energy performance, fuel efficiency or environmental standards that already exist in a growing number of countries" as a crucial innovation.

Finally, it can be noted that while climate change is certainly the major aspect for the liability side of an insurer's balance sheet, other sustainability aspects such as social and governance issues might also play a role in D\&O policies and reputation risk insurance contracts, and social risks in the context of an ageing population (of relevance for life \& pension insurance) are mentioned by the UNEP FI (2009) or Nogueira et al. (2018). Inclusive insurance ${ }^{31}$ or the already mentioned microinsurance policies represent further examples. In this context, the GIZ (2017) highlights the relevant SDGs for the liability side, where six goals ${ }^{32}$ are identified with insurance having a primary level contribution, i.e. a direct and self-evident impact. For five goals ${ }^{33}$, insurance has a secondary level contribution or a rather indirect impact.

\subsubsection{How to deal with sustainability risks and opportunities on the liability side}

To assess sustainability risks on the liability side, (medium- and long-term) scenario analyses can be applied as is done in, e.g., Kunreuther et al. (2013b) in regard to high or low climate change scenarios that address yearly loss rates as well as projections until 2020 and 2040, thereby also taking into account adaptation measures. This is important, as increasing losses can (partially) be reduced by prevention and adaptation strategies, i.e. physical loss reduction measures (Herweijer et al. (2009, pp. 365-366) naming, e.g., more resilient buildings against flood and hazard defenses), which is also relevant concerning the question of insurability. Using scenario analyses for Florida hurricane activity projections and thus future climate variability in terms of high vs. low climate change scenarios, Kunreuther et al. (2013b) provide a first quantitative assessment how the implementation of adaptation measures, also depending on insurance market conditions and reinsurance, influences premiums and thus the affordability and availability of property insurance coverage against losses from hurricane risk. They find that premiums could almost be cut in half in case of fully adopting the physical property-level resistance and resilience measures according to the Florida Building Code 2004, and that a strong and competitive reinsurance market is also vital to ensure availability. However, the authors do not take into account the costs or the climate impact of using a building material other than wood, for instance. An extensive overview on possible measures and solutions with regard to (alternative) risk transfer and reduction in the context of climate change is derived in Stechemesser et al. (2015, p. 565) from the academic literature.

\footnotetext{
31 GIZ (2017, p. 37) defines inclusive insurance as "a strategy to promote broad-based access to insurance for the 'un- and underserved' and includes different classes of insurance".

32 I.e. no poverty (1), zero hunger (2), good health and well-being (3), gender equality (5), decent work and economic growth (8), climate action (13) (GIZ 2017, p. 10).

33 I.e. quality education (4), industry, innovation and infrastructure (9), reduced inequalities (10), sustainable cities and communities (11), partnerships for the goals (17) (GIZ 2017, p. 25).
} 
Also of relevance are the recommendations of the TCFD (2017b) as presented in Sect. 3.1, this time with focus on the impact of climate change on the insurer's liability side (and with the same limitations in regard to scaling to certain regions etc.). In addition to scenario analyses, stress tests should be conducted. The German supervisory authority BaFin (2020, p. 34) thereby recommends to check whether stress tests sufficiently reflect potential sustainability risks for the firm, and to potentially adjust them. References listed include climate-related stress tests for supervisory purposes (i.e. not necessarily suitable for management decisions, but as a first indication for firm-specific analyses) currently developed by the Network of Central Banks and Supervisors for Greening the Financial System (NGFS), the European Systemic Risk Board, the European Central Bank and the German Central Bank.

Finally, it is worth noting that a quantitative assessment of climate-related risks on the liability side and the value of preventive measures and climate policies is highly challenging given the uncertainty and lack of consensus, e.g. in regard to likelihood and outcome (Kunreuther et al. 2013a). As standard approaches are hardly applicable, Kunreuther et al. (2013a) suggest the use of more robust decision-making instruments to assess climate policies where stakeholders have different risk tolerance levels and distribution functions are not (fully) available. ${ }^{34}$ They discuss the application of different robust concepts using the case of a Florida coastal community as an example that has to decide about whether to allow building a residential facility on the coast. First, as climate models in physical scenarios result in ranges of outcomes, but do not provide entire probability distributions, the authors suggest using a "safety-first" approach where extreme outcomes with very low likelihood below a threshold are not taken into account. Second, in case of ambiguity, where a distribution function is available but with strong variations across different models and thus not objectively defined, as is the case for estimates of the "equilibrium climate sensitivity", decision-making approaches from the literature can be applied that do not require well-defined probabilities. Third, non-probabilistic approaches such as the minimax regret approach can be used if probabilities of outcomes are entirely unknown.

\subsubsection{Empirical insight from the literature and (industry) surveys on current practices}

The results of the Geneva Association survey in Golnaraghi (2018) largely confirm the consideration of the previously presented risks and opportunities for (re-) insurance companies in practice, e.g. risk reduction and transfer, (green) product and service innovation or enhancement and microinsurance. Products tailored for governmental needs and research support represent further relevant measures. External challenges, which hamper (re-)insurers' contributions against climate change are derived as well, as summarized in Table 2.

\footnotetext{
34 See, e.g., Kunreuther et al. (2013a, p. 448) for a graphical illustration with various estimated density functions for the equilibrium climate sensitivity and corresponding $\mathrm{CO} 2$ concentrations in accordance with a long-term $\mathrm{CO} 2$-induced temperature increase of $2{ }^{\circ} \mathrm{C}$.
} 
Table 2 External barriers preventing insurers to expand their risk transfer solutions on the liability side (Geneva Association report, Golnaraghi 2018, p. 24)

Limited access to risk information and related risk pricing difficulties

Public policy, regulatory and legislative issues

Lack of awareness about insurance

Weakness of domestic insurance markets

Limited take-up of disaster insurance

Regulatory barriers to access global reinsurance

Scalability and sustainability of insurance programmes

In addition to working together with other institutional investors on the asset side in the context of engagement (active ownership) with the aim to address sustainability risks and opportunities at the investee level, insurers increasingly collaborate with other external stakeholders in order to transfer climate knowledge and build resilience against climate change (e.g., UNEP 2017, p. 10; Golnaraghi 2018, p. 18).

\subsection{Sustainability risks and opportunities from a corporate perspective}

\subsubsection{Sustainability risks and opportunities from a corporate perspective: overview}

As sustainability risks can have severe negative effects on all business units and risk types, from a more corporate perspective, insurers also face various operational risks, strategic risks, and reputational risks (BaFin 2020). Operational risks might occur due to physical climatic events damaging assets as well as affecting the safety and continuity of insurance operations (IAIS 2018).

A strategic risk would arise, for instance, if an insurer fails to adapt to structural changes in the sector, driven by, e.g., the transition to a low-carbon economy and thus not accomplishing strategic goals (IAIS 2018). Furthermore, reputation risk (as a strategic risk) might materialize if the insurer invests in a firm with inadequate safety measures in regard to buildings or working conditions (despite satisfying official requirements), leading to severe and numerous casualties that are reported in the media (BaFin 2020, p. 18). Reputation risks would also arise from false advertising, i.e. greenwashing, or omitting the implementation of "proper" sustainable measures as perceived by external and internal stakeholders (Mills 2009, p. 346; BaFin 2020, pp. 15-18). This reputation risk potential associated with sustainability risks on the asset and liability side led several insurers to divest from coal and ultimately stop insuring the coal mining industry, as was communicated by, e.g. Allianz in $2018 .{ }^{35}$

On the other side, a reputation reward through sustainable business practices in general is addressed in Herweijer et al. (2009). Based on the identification of sectorspecific material ESG or sustainability issues and topics, Clark et al. (2015, p. 13) further point out risk (firm-related risks and external costs), performance (process and product innovation) and reputation (human resources and consumers) as "three

\footnotetext{
35 https://www.ft.com/content/a23a6c3c-4eec-11e8-9471-a083af05aea7, access 05/20/2020.
} 
major ways how sustainability through the integration of environmental, social and governance [...] issues can lead to a competitive advantage".

Besides diversity on the management or board level (Rao and Tilt 2016, p. 340), workforce diversity ${ }^{36}$ and inclusion are major sustainability issues, also being considered in the SDGs 5 ("Achieve gender equality and empower all women and girls") and 10 ("Reduce inequality within and among countries"). ${ }^{37}$ In addition to promoting corporate sustainability and achieving the SDGs, diversity and inclusion represent opportunities to enhance an insurer's spectrum of (potential) job applicants, customer satisfaction as well as to thrive innovation through introducing different perspectives, among other aspects. ${ }^{38}$ In particular, decent places in diversity and inclusion rankings can positively affect reputation. ${ }^{39}$

\subsubsection{How to deal with sustainability risks and opportunities from a corporate perspective}

Recommendations to establish inclusion and diversity include creating an awareness for diversity, communicate benefits and monitor workforce and board composition. ${ }^{40}$ Insurance companies might also use the methodologies of the aforementioned rankings as a guideline to promote diversity and inclusion within the firm. ${ }^{41}$

In general, insurers should further develop a new or adjust their current business strategy to integrate sustainability risks and opportunities (BaFin 2020, p. 19). This also includes the risk strategy and communication ${ }^{42}$ (BaFin 2020, p. 21). With respect to governance, the BaFin (2020, p. 22) highlights the importance of an understanding of sustainability risks and opportunities for the management board, a clear definition of roles and responsibilities, including the consideration in incentive systems and compensation structures (e.g., Fabrizi et al. 2014), as well as the role model function of the management board.

Concerning the risk management in general, Mills (2009) already pointed out that climate change is a typical enterprise risk management issue due to its overarching

\footnotetext{
36 With respect to defining (board) diversity, Rao and Tilt (2016, pp. 328-329) refer to heterogeneity among people (or members of the board). They further cite van Knippenberg et al. (2004, p. 1008), who point out that an almost indefinite number of dimensions can be attributed to the concept of diversity, including but not limited to age, nationality, religion, skills or political orientation.

37 https://sustainabledevelopment.un.org/?menu=1300, access 06/02/2020.

38 https://www.pwc.be/en/documents/20161108-diversity-and-inclusion-pwc-be.pdf, access 08/25/2020.

39 Examples for such rankings include the globally oriented Refinitiv Diversity and Inclusion Index (https://www.refinitiv.com/en/financial-data/indices/diversity-and-inclusion-index, access 08/25/2020) or the recently introduced European-related Diversity Leaders ranking by Statista and the Financial Times (https://www.ft.com/reports/diversity-leaders, access 08/25/2020).

40 https://www.pwc.be/en/documents/20161108-diversity-and-inclusion-pwc-be.pdf, access 08/25/2020.

41 See also the EU Directive 2014/95/EU (non-financial reporting), which requires certain large firms to disclose or explain the (non-)existence of a diversity policy and how they deal with social and employeerelated matters, among others. (https://eur-lex.europa.eu/legal-content/EN/TXT/PDF/?uri=CELEX: 32014L0095\&from=DE, access 08/28/2020).

42 See, e.g., BaFin (2020, p. 20) on mandatory and voluntary corporate disclosure frameworks such as the aforementioned EU Directive 2014/95/EU, the TCFD (2017a) recommendations or the Sustainability Code with relevance for counterparties, (potential) investment targets and insurers, respectively.
} 
impact on underwriting, investments and corporate governance. ${ }^{43}$ Stechemesser et al. (2015, p. 563) further emphasize that the "potentially occurring risks could lead to increasing capital costs, [...] increasing operational costs, [...] decreasing fixed assets arising from property depreciation" and as a result leading to reduced profitability. Therefore, taking into account liability, transition and physical risks on a corporate level and a result of scenario analyses should be helpful. Mills (2009, p. 352) also suggests to participate in dialogues on public policies concerning climate change, which is in line with Herweijer et al. (2009, p. 371) who suggest that insurers should play a supporting role and have constructive relationships with policymakers, regulators, and other parts of the private sector-all aspects that are still relevant today.

Insurers, irrelevant of their geographic location, can also make use of the US NAIC Climate Risk Disclosure Survey Guidance together with its explanations and "questions to consider" as a reference point for challenging and matching their own climate change strategy. ${ }^{44}$

\subsubsection{Empirical insight from the literature and (industry) surveys on current practices}

Based on the aforementioned US NAIC Climate Risk Disclosure Survey from 2012 and 2015, Thistlethwaite and Wood (2018) find that only few insurers integrate a climate change risk management in their investment process and insurance business, with reinsurers being more involved than primary insurers. However, in the Geneva Association report, Golnaraghi (2018) observes that all 21 (re-)insurers included in the international survey consider climate change at least to some extent. While one third treat climate change as an environmental and sustainability issue, $29 \%$ are moving forward to increasingly implement it as a core business issue. The remaining (re-)insurers already fully accept and integrate climate change as a core business issue with its risks and opportunities in their strategy and operations as well as in their governance and risk management systems. ${ }^{45}$

With regard to transparency on climate-related risks and opportunities, the AODP\&SA (2018) survey finds a discrepancy concerning published information on risks and opportunities by the world's 80 largest (re-)insurers. While $69 \%$ of the sample publish climate-related risk information, only $41 \%$ report opportunities resulting from climate change. By applying the TCFD (2017a) framework as a benchmark, the survey further identifies regional differences and, similar to

\footnotetext{
43 Though being published more than one decade ago, Mills (2009, pp. 351-354) also offers a checklist concerning first steps and a best practices overview for insurance companies, which are still relevant.

44 The annually uploaded questions and guidance document is available on the NAIC Climate Risk Disclosure Survey Results webpage and includes questions, for instance, concerning the (non-)existence of a climate change policy (risk and investment management) or (missing) actions on building customer resilience or catastrophe modeling. Yearly responses are available as well (http://www.insurance.ca.gov/ 0250-insurers/0300-insurers/0100-applications/ClimateSurvey/index.cfm, access 07/01/2020).

45 See the Geneva Association report by Golnaraghi (2018, p. 17) for examples concerning the different integration levels.
} 
Thistlethwaite and Wood (2018), a disparity among the different insurance business types as well as a lack of appropriate metrics and targets.

In this context, the UNEP (2017, p. 11) report notes that despite large (re-)insurance companies lead the sustainable insurance transformation, a large proportion of insurers lags behind with existing impediments such as different insurance business areas being exposed to environmental risks to varying degrees, misalignment of market incentives or limitations in capacity. The ideal sustainable insurance regime is thereby understood as improving resilience through sustaining and enhancing access, affordability and insurability, reducing risks and exposures through risk management, innovation, prevention, as well as investing in green and robust assets.

With respect to green assets, insurance companies might not only contribute as investors to the greening of buildings and realize higher prices or rents, but also benefit as green building occupants. Reduced operating expenses, improved amenities, employee health and productivity, corporate reputation as well as environment protection represent major benefits and are also seen as possible determinants for the green premium. However, a definite answer whether the benefits outweigh the costs is not possible yet and requires more (empirical) research (Zhang et al. 2018).

\subsection{Does "sustainability" create value for insurance companies?}

Against the background of the previously discussed aspects, the question arises whether the management of sustainability risks and opportunities as laid out above can create value for insurance companies. The empirical evidence on this is generally mixed.

Concerning the question of performance of sustainable investments, evidence strongly depends on the applied investment strategy. Clark et al. (2015, p. 42) conclude in their summary of 41 studies that stock market investors who incorporate ESG criteria in their investment decision process can benefit in terms of enhanced financial market performance, ${ }^{46}$ while Friede et al. (2015, p. 226) in contrast highlight missing evidence for a superior impact on the performance by the three single ESG criteria. In line with the latter, further reviews and meta-analyses indicate, for instance, a neutral performance of screened portfolios (Friede et al. 2015; Revelli and Viviani 2015; Brooks and Oikonomou 2018). ${ }^{47}$ However, with reference to a review from 2014 of more than 60 academic empirical analyses, Golnaraghi (2018, p. 20) points out that even though about $80 \%$ of the studies did not find significant differences between ESG portfolios and benchmarks, there might still be a future climate risk premium as countries increase their regulations and efforts to achieve

\footnotetext{
46 The review of the studies indicates an overall positive relation between investment performance and the performance on an aggregate ESG-level as well as for the constituent E- (i.e. environmentally related responsible conduct and efficiency as major factors), S- (i.e. employee relations and satisfaction as major factors) and G-dimension (Clark et al. 2015, p. 42).

47 See Friede et al. (2015, pp. 225-226) for a discussion of this relation. Their results also indicate outperformance opportunities for bonds and real estate investments as they divide their data into equity and nonequity.
} 
a reduction in greenhouse gas emissions and due to higher transparency of climate risk exposures in the future, causing discounts (or increases) of firm value.

In addition, early empirical insight on the impact of insurers' adaptation measures specifically to climate change on corporate financial performance can be found in Stechemesser et al. (2015), based on 59 international insurers' responses to the Carbon Disclosure Project in 2009. Using a framework with three dynamic capability dimensions of climate change adaptation, namely climate knowledge absorption ${ }^{48}$, climate-related operational flexibility ${ }^{49}$, and strategic climate integration ${ }^{50}$, they find a positive relationship between the first two dimensions and the return on assets, but not for strategic climate integration. They also find a positive relationship between the total number of adaptation measures and return on assets.

From a more general corporate perspective, within their aggregated sample of around 2200 studies, Friede et al. (2015, p. 226), for instance, find that the majority shows a positive relation between ESG and various corporate financial performance measures, but do not find support that one ESG dimension is dominant. About $90 \%$ of the studies in their sample resulted in a nonnegative relation. In contrast, the OECD (2017, p. 32) sees a trend within the literature towards inconclusive results in regard to the relation between ESG and (corporate) financial performance, especially for contributions from 2000 to 2010 .

In a meta-analysis of 25 meta-analyses comprising almost one million observations, Busch and Friede (2018) observe a highly significant, positive, robust, and bilateral relation between corporate social/environmental performance and corporate financial performance, which is independent of an ecological or social focus and with corporate reputation being a key corporate social/environmental performance determinant. Vishwanathan et al. (2020) further conduct a meta-analytical analysis of 344 studies on four attributes, namely 1) enhancing firm reputation, 2) increasing stakeholder reciprocation, 3) mitigating firm risk, and 4) strengthening innovation capacity, which combined explain about $20 \%$ of the relationship between (strategic) CSR and corporate financial performance.

\section{Summary}

This paper discusses sustainability risks and opportunities from the perspective of the insurance industry. We contribute to the literature by offering a structured presentation of sustainability risks and opportunities on the asset side, the liability side, as well as from a more general corporate perspective. After providing an overview of definitions and the terminology along with relevant regulatory initiatives, we distinguish between the asset side, the liability side, and the corporate perspective and

\footnotetext{
48 I.e., understanding the climate change problem, building awareness and participating in public policy (Stechemesser et al. 2015, p. 566).

49 I.e., aligning terms and conditions with risk-reducing behavior, (alternative) risk transfer/risk reducing mechanisms (Stechemesser et al. 2015, p. 567).

50 I.e., new insurance products and services, (re-)investments in climate change solutions, financing customer improvements (Stechemesser et al. 2015, p. 567).
} 
respectively discuss the risks and opportunities as well as approaches how insurers can respond, followed by selected empirical insight on industry practices with main focus on the European market. We conclude with a short review whether "sustainability" creates value for firms.

Our study shows that while climate change is highly relevant, numerous other aspects should be taken into account as well, and that insurers should thus take a broad approach on managing sustainability risks and opportunities. We also emphasize various key barriers, in particular a lack of knowledge, standardization and data, which also reduce transparency and comparability between firms, especially against the background of the planned reporting requirements in the EU. In the context of asset management, this could be improved by providing an EU wide public register for (reliable) ESG data as called for by the European Banking Federation and several other financial industry associations. ${ }^{51}$

Once a higher degree of transparency and standardization is reached (as opposed to the currently strongly diverging ESG asset ratings with multiple measurement approaches, for instance), the degree of consideration of sustainability risks and opportunities regarding assets, liabilities, and the overall corporate perspective in insurance companies will be increasingly relevant as a competitive differentiator in the market.

Funding Open Access funding enabled and organized by Projekt DEAL.

Open Access This article is licensed under a Creative Commons Attribution 4.0 International License, which permits use, sharing, adaptation, distribution and reproduction in any medium or format, as long as you give appropriate credit to the original author(s) and the source, provide a link to the Creative Commons licence, and indicate if changes were made. The images or other third party material in this article are included in the article's Creative Commons licence, unless indicated otherwise in a credit line to the material. If material is not included in the article's Creative Commons licence and your intended use is not permitted by statutory regulation or exceeds the permitted use, you will need to obtain permission directly from the copyright holder. To view a copy of this licence, visit http://creativecommons.org/licenses/by/4. $0 /$.

\section{References}

Asset Owners Disclosure Project \& ShareAction (AODP\&SA): Got it covered? Insurance in a changing climate (2018). https://aodproject.net/wp-content/uploads/2018/05/AODP-Got-It-Covered-InsuranceReport-2018.pdf, Accessed 20 July 2020

Brooks, C., Oikonomou, I.: The effects of environmental, social and governance disclosures and performance on firm value: a review of the literature in accounting and finance. Br. Account. Rev. 50(1), $1-15$ (2018)

Bundesanstalt für Finanzdienstleistungsaufsicht (BaFin): Guidance notice on dealing with sustainability risks (2020). https://www.bafin.de/SharedDocs/Downloads/EN/Merkblatt/dl_mb_Nachhaltigkeitsrisi ken_en.pdf?_blob=publicationFile \&v=5, Accessed 5 July 2020

Busch, T., Friede, G.: The robustness of the corporate social and financial performance relation: a secondorder meta-analysis. Corp. Soc. Responsib. Environ. Manag. 25(4), 583-608 (2018)

Carney, M.: Breaking the tragedy of the horizon-climate change and financial stability (2015). https:// www.bankofengland.co.uk/-/media/boe/files/speech/2015/breaking-the-tragedy-of-the-horizonclimate-change-and-financial-stability.pdf?la=en\&hash=7C67E785651862457D99511147C7424FF 5EA0C1A, Accessed 8 June 2020

\footnotetext{
51 https://www.ebf.eu/ebf-media-centre/a-centralized-register-for-esg-data-in-eujoint-letter/,
} $09 / 17 / 2020$.

access 
Clark, G.L., Feiner, A., Viehs, M.: From the stockholder to the stakeholder-how sustainability can drive financial outperformance (2015). https://arabesque.com/research/From_the_stockholder_to_ the_stakeholder_web.pdf, Accessed 28 June 2020

Deutsche Gesellschaft für Internationale Zusammenarbeit (GIZ): Inclusive insurance and the Sustainable Development Goals - how insurance contributes to the 2030 Agenda for Sustainable Development (2017). https://microinsurancenetwork.org/sites/default/files/Inclusive\%20Insurance\%20and \%20the\%20Sustainable\%20Development\%20Goals\%20.pdf, Accessed 2 July 2020

Dorfleitner, G., Halbritter, G., Nguyen, M.: Measuring the level and risk of corporate responsibility-an empirical comparison of different ESG rating approaches. J. Asset Manag. 16(7), 450-466 (2015)

Fabrizi, M., Mallin, C., Michelon, G.: The role of CEO's personal incentives in driving corporate social responsibility. J. Bus. Ethics 124(2), 311-326 (2014)

Friede, G., Busch, T., Bassen, A.: ESG and financial performance: aggregated evidence from more than 2000 empirical studies. J. Sustain. Finance Invest. 5(4), 210-233 (2015)

Gatzert, N., Kosub, T.: The impact of European initiatives on the treatment of insurers' infrastructure investments under Solvency II. Geneva Pap. Risk Insur. Issues Pract. 42(4), 708-731 (2017)

Gatzert, N., Reichel, P.: Awareness of climate risks and opportunities: empirical evidence on determinants and value from the US and European insurance industry. Working Paper, Friedrich-Alexander University Erlangen-Nürnberg, Nuremberg (2020a)

Gatzert, N., Reichel, P.: Sustainable investing in the US and European insurance industry: a text mining analysis. Working Paper, Friedrich-Alexander University Erlangen-Nürnberg, Nuremberg (2020b)

Global Sustainable Investment Alliance (GSIA): Global sustainable investment review 2018 (2019). http:// www.gsi-alliance.org/wp-content/uploads/2019/03/GSIR_Review2018.3.28.pdf, Accessed 19 Jan 2020

Golnaraghi, M.: Climate change and the insurance industry: taking action as risk managers and investors. Perspectives from C-level executives in the insurance industry. The Geneva Association (2018). https://www.genevaassociation.org/sites/default/files/research-topics-document-type/pdf_public// climate_change_and_the_insurance_industry_-_taking_action_as_risk_managers_and_investors. pdf, Accessed 15 June 2020

Herweijer, C., Ranger, N., Ward, R.E.T.: Adaptation to climate change: threats and opportunities for the insurance industry. Geneva Pap. Risk Insur. Issues Pract. 34(3), 360-380 (2009)

International Association of Insurance Supervisors (IAIS): Issues paper on climate change risks to the insurance sector (2018). https://www.iaisweb.org/page/supervisory-material/issues-papers/file/76026/ sif-iais-issues-paper-on-climate-changes-risk, Accessed 2 July 2020

van Knippenberg, D., De Dreu, C.K.W., Homan, A.C.: Work group diversity and group performance: an integrative model and research agenda. J. Appl. Psychol. 89(6), 1008-1022 (2004)

Krogstrup, S., Oman, W.: Macroeconomic and financial policies for climate change mitigation: a review of the literature. Working Paper, IMF Working Paper, WP/19/185 (2019)

Kunreuther, H., Heal, G., Allen, M., Edenhofer, O., Field, C.B., Yohe, G.: Risk management and climate change. Nat. Clim. Chang. 3(5), 447-450 (2013a)

Kunreuther, H., Michel-Kerjan, E., Ranger, N.: Insuring future climate catastrophes. Clim. Chang. 118(2), 339-354 (2013b)

Maynard, T.: Climate change: impacts on insurers and how they can help with adaptation and mitigation. Geneva Pap. Risk Insur. Issues Pract. 33(1), 140-146 (2008)

Mills, E.: A global review of insurance industry responses to climate change. Geneva Pap. Risk Insur. Issues Pract. 34(3), 323-359 (2009)

Nogueira, F.G., Lucena, A.F.P., Nogueira, R.: Sustainable insurance assessment: towards an integrative model. Geneva Pap. Risk Insur. Issues Pract. 43(2), 275-299 (2018)

OECD: Investment governance and the integration of environmental, social and governance factors (2017). http://www.oecd.org/investment/Investment-Governance-Integration-ESG-Factors.pdf, Accessed 1 July 2020

PRI Association: Impact investing market map (2018a). https://www.unpri.org/download?ac=5426, Accessed 4 June 2020

PRI Association: PRI reporting framework-main definitions (2018b). https://d8g8t13e9vf2o.cloudfront. net/Uploads/d/t/z/maindefinitionstoprireportingframework_127272.pdf, Accessed 4 June 2020

Rao, K., Tilt, C.: Board composition and corporate social responsibility: the role of diversity, gender, strategy and decision making. J. Bus. Ethics 138(2), 327-347 (2016)

Revelli, C., Viviani, J.-L.: Financial performance of socially responsible investing (SRI): what have we learned? A meta-analysis. Bus. Ethics Eur. Rev. 24(2), 158-185 (2015) 
Risi, D.: Time and business sustainability: socially responsible investing in Swiss banks and insurance companies. Bus. Soc. 59(7), 1410-1440 (2020)

Scholtens, B.: Corporate social responsibility in the international banking industry. J. Bus. Ethics 86(2), $159-175$ (2009)

Scholtens, B.: Corporate social responsibility in the international insurance industry. Sustain. Dev. 19(2), $143-156(2011)$

Scordis, N.A., Suzawa, Y., Zwick, A., Ruckner, L.: Principles for Sustainable Insurance: risk management and value. Risk Manag. Insur. Rev. 17(2), 265-276 (2014)

Standard \& Poor's Ratings Services: Storm alert: natural disasters can damage sovereign creditworthiness (2015). https://unepfi.org/pdc/wp-content/uploads/StormAlert.pdf, Accessed 8 June 2020

Stechemesser, K., Endrikat, J., Grasshoff, N., Guenther, E.: Insurance companies' responses to climate change: adaptation, dynamic capabilities and competitive advantage. Geneva Pap. Risk Insur. Issues Pract. 40(4), 557-584 (2015)

Surminski, S., Roezer, V., Golnaraghi, M.: Flood risk management in Germany. Building flood resilience in a changing climate. The Geneva Association, June 2020 (2020). https://www.genevaassociation. $\mathrm{org} / \mathrm{sites} /$ default/files/flood-risk-management-germany.pdf, Accessed 17 Sept 2020

Swiss Re: Power up: investing in infrastructure to drive sustainable growth in emerging markets (2020). https://www.swissre.com/institute/research/sigma-research/sigma-2020-03.html, Accessed 18 June 2020

Task Force on Climate-related Financial Disclosures (TCFD): Final report: recommendations of the Task Force on Climate-related Financial Disclosures (2017a). https://www.fsb-tcfd.org/wp-content/ uploads/2017/06/FINAL-2017-TCFD-Report-11052018.pdf, Accessed 25 Aug 2020

Task Force on Climate-related Financial Disclosures (TCFD): Technical supplement: the use of scenario analysis in disclosure of climate-related risks and opportunities (2017b). https://www.fsb-tcfd.org/ publications/final-technical-supplement/, Accessed 19 May 2020

Thistlethwaite, J., Wood, M.O.: Insurance and climate change risk management: rescaling to look beyond the horizon. Br. J. Manag. 29(2), 279-298 (2018)

UN Environment: Navigating a new climate-part 2: physical risks and opportunities (2018). https:// www.unepfi.org/wordpress/wp-content/uploads/2018/07/NAVIGATING-A-NEW-CLIMATE.pdf, Accessed 19 May 2020

UNEP FI: The global state of sustainable insurance-understanding and integrating environmental, social and governance factors in insurance (2009). https://www.unepfi.org/fileadmin/documents/globalstate-of-sustainable-insurance_01.pdf, Accessed 28 Aug 2020

UNEP FI: PSI-Principles for Sustainable Insurance-a global sustainability framework and initiative of the United Nations Environment Programme Finance Initiative (2012). https://www.unepfi.org/psi/ wp-content/uploads/2012/06/PSI-document.pdf, Accessed 20 Aug 2020

United Nations Environment Programme (UNEP): Sustainable insurance- the emerging agenda for supervisors and regulators (2017). https://b9ea8c1e-dc19-4d5f-b149-9b1ea4b8d050.filesusr.com/ugd/ eb1f0b_0496a436802446f9a54b09c439417d0f.pdf, Accessed 3 June 2020

United Nations Environment Programme (UNEP): Extending our horizons-part 1: transition-related risks \& opportunities (2018). https://www.unepfi.org/wordpress/wp-content/uploads/2018/ 04/EXTENDING-OUR-HORIZONS.pdf, Accessed 19 May 2020

US SIF Foundation (USSIF): Report on US Sustainable, Responsible and Impact Investing Trends 2018. US SIF Foundation, Washington DC (2018)

Vishwanathan, P., van Oosterhout, H.J., Heugens, P.P.M.A.R., Duran, P., van Essen, M.: Strategic CSR: a concept building meta-analysis. J. Manag. Stud. 57(2), 314-350 (2020)

World Commission on Environment and Development: Our common future (1987). https://www.un.org/ ga/search/view_doc.asp?symbol=A/42/427\&Lang=E, Accessed 2 June 2020

Zhang, L., Wu, J., Liu, H.: Turning green into gold: a review on the economics of green buildings. J. Clean. Prod. 172, 2234-2245 (2018) 